Katarzyna Kopeć iD https://orcid.org/0000-0002-2426-0275

Uniwersytet Jagielloński

e-mail: katarzyna.kopec@uj.edu.pl

Marta Materska-Samek iD https://orcid.org/0000-0002-4432-0933

Uniwersytet Jagielloński

e-mail: m.materska-samek@uj.edu.pl

Otrzymano/Received: 20.01.2021

Zaakceptowano/Accepted: 15.03 .2021

Opublikowano/Published: 27.05.2021

\title{
Fundusz Wsparcia Kultury - rekompensata strat czy strategiczna interwencja?
}

\author{
Abstract \\ The Culture Support Fund - COVID-19 Compensation or a Strategic \\ Intervention?
}

The aim of the paper is to discuss the Cultural Support Fund (CSF) as an example of a reactive financing scheme. In order to understand the implemented compensation mechanism for entities operating in the creative sector, a broader context is also explored, which, on the one hand, shows the general message of the Fund, and on the other hand, the lack of efficient management of the CSF. The research is based on the analysis of the existing data outlining the operation of private enterprises in the creative sector, with the emphasis on the performing arts backstage industry. The drama of the situation is accentuated in the individual in-depth interviews with four beneficiaries of the Culture Support Fund, which presents the perspective of the CSF recipients. In order to stress the multidimensionality of the CSF structure, the conclusions are built according to the three dimensions of the analysis: procedural, substantive, and contextual.

Keywords: creative industries, performing arts, backstage, Culture Support Fund (CSF), reactive support scheme, COVID-19

Słowa kluczowe: przemysły kreatywne, działalność estradowo-sceniczna, scenotechnika, Fundusz Wsparcia Kultury (FWK), wsparcie reaktywne, COVID-19 
Wstęp

"Pierwsi do zamknięcia, ostatni do otwarcia”

[Czyżewski i in. 2020]

Wprowadzony reżim sanitarny pozbawił przemysły kultury i kreatywne, w tym cały sektor estradowo-sceniczny możliwości funkcjonowania. By zobaczyć skalę proble$\mathrm{mu}$, trzeba zrozumieć charakter tego sektora. To bowiem w przeważającej większości zbiór przedsiębiorstw, których liczbę GUS oszacował na 117,2 tys. w 2018 roku, w tym przeważającą większość podmiotów $(98,9 \%)$ stanowiły mikroprzedsiębiorstwa, skupiające $70,5 \%$ pracujących w obszarze przemysłów kultury i kreatywnych [GUS 2018]. Wśród działalności związanych z organizacją wydarzeń artystycznych prowadzonych w ramach działalności gospodarczej znajdziemy muzykę, teatr, taniec oraz wspierającą realizację wydarzeń - scenotechnikę.

W sytuacji obostrzeń sanitarnych wprowadzonych w trakcie pandemii koronawirusa rządy wielu państw podjęły prace w zakresie przeciwdziałania skutkom ekonomicznym w obszarze kultury i przemysłów kreatywnych. W Polsce jednym z mechanizmów wsparcia służącym utrzymaniu funkcjonowania podmiotów w ramach przemysłów kreatywnych był Fundusz Wsparcia Kultury (FWK). Zaprojektowany jako strategiczne narzędzie interwencji w celu ratowania miejsc pracy oraz podmiotów gospodarczych, wpisywał się w nurt mechanizmów reaktywnych uruchamianych w wielu państwach europejskich. Reaktywność wsparcia jasna była jednak tylko dla niektórych beneficjentów Funduszu. Część wnioskodawców odczytała intencję FWK jako zachętę do kreatywności i innowacyjności. Przede wszystkim jednak brak klarownego i jednoznacznego zaprezentowania głównego celu wsparcia oraz pośpiech we wdrażaniu tego mechanizmu zaowocowały pojawieniem się kontrowersji wokół listy beneficjentów i kwot wsparcia.

Celem artykułu jest przedstawienie Funduszu Wsparcia Kultury jako przykładu instrumentu finansowania o charakterze reaktywnym. By zrozumieć wdrożony mechanizm rekompensat dla podmiotów działających w przemysłach kreatywnych, omówiona zostanie zarówno sama koncepcja FWK, jak i szerszy kontekst umożliwiający zrozumienie funkcji i celu FWK w ramach polityki kulturalnej. Zastosowanym narzędziem jest w pierwszej kolejności analiza danych zastanych, co umożliwi zaznajomienie się z uwarunkowaniami funkcjonowania podmiotów ze szczególnym uwzględnieniem branży scenotechnicznej. Dramaturgię sytuacji tego obszaru podkreślono $\mathrm{w}$ indywidualnych wywiadach pogłębionych $\mathrm{z}$ czterema beneficjentami Funduszu Wsparcia Kultury, których celem było przedstawienie FWK z perspektywy beneficjentów wsparcia. Wnioski zostały zbudowane według trzech wymiarów analizy: wymiaru proceduralnego, merytorycznego i kontekstualnego, umożliwiającej pokazanie wielowymiarowości konstrukcji FWK. 


\section{Publiczne mechanizmy wspierania kultury w czasie pandemii}

Na źródła finansowania działalności kulturalnej w Polsce składają się - w znacznym uogólnieniu - instrumenty finansowe pochodzące ze środków budżetowych (publicznych) oraz instrumenty finansowe pochodzące ze środków pozabudżetowych (niepublicznych) [Kopeć 2014]. Główną rolę w mechanizmie wspierania kultury odgrywają jednak środki publiczne, w tym subwencje, tj. świadczenia publicznoprawne państwa na rzecz innych podmiotów publicznych - o charakterze bezzwrotnym, ogólnym, bezwarunkowym i nieodpłatnym [Leksykon budżeto$w y$ ] - oraz granty (dotacje) mające charakter uznaniowy [Ilczuk 2012], zazwyczaj przyznawane w wyniku konkursu. Granty można zdefiniować jako proaktywne instrumenty finansowania, służące wyborowi najlepszych projektów spełniających określone w konkursie kryteria. Środki grantowe mają zatem charakter instrumentalny, ponieważ służą określonym celom, na przykład realizacji polityki kulturalnej, przez taki dobór kryteriów konkursowych, by zwycięskie projekty poświęcone były sprecyzowanej tematyce, włączały określone grupy docelowe lub by ich realizacja odbywała się w danym regionie etc.

- W odpowiedzi na pandemię koronawirusa rządy wielu państw podjęły prace w zakresie przeciwdziałania skutkom ekonomicznym w obszarze branży kreatywnej. W pierwszej kolejności były to narzędzia skierowane do MŚP (jako podmiotów dominujących w kulturze), bezrobotnych artystów, freelancerów (nieobjętych ubezpieczeniem społecznym) i branż szczególnie dotkniętych skutkami pandemii (np. sztuki performatywne) [Pasikowska-Schnass 2020]. Państwa działały w tym zakresie dość elastycznie, wprowadzając różne rozwiązania finansowe pośrednie i bezpośrednie, na przykład przedłużenie terminów płatności podatków, pomoc dla podmiotów gospodarczych na utrzymanie płynności finansowej w formie gwarancji na zabezpieczenie pożyczek i dopłat do ich oprocentowania itd. Państwa europejskie w trakcie pierwszej fazy pandemii (marzec-maj 2020) wdrożyły wiele schematów wsparcia [Betzler i in. 2020] w zakresie: zatrudnienia (wsparcie polegało zazwyczaj na udzielaniu długoterminowych pożyczek, dofinansowaniu do zatrudnienia, przedłużeniu postojowego czy zwolnieniu ze składek na ZUS. Niektóre państwa wdrożyły rozwiązania dla samozatrudnionych, na przykład $\mathrm{w}$ formie bezzwrotnej bezpośredniej finansowej rekompensaty), rozwiązań fiskalnych (wsparcie w formie odroczenia płatności podatku lub składek na ubezpieczenia społeczne dla poprawy płynności firmy, niektóre państwa podjęły decyzję o nienakładaniu kar za opóźnione złożenie deklaracji podatkowej czy opłatę podatku), przeznaczania środków na utrzymanie funkcjonowania podmiotów, w tym środków skierowanych bezpośrednio do sektora kultury i przemysłów kreatywnych (wsparcie objęło tu np. pożyczki, kredyty gwarantowane, różne formy rekompensat, bezzwrotne dotacje, zniżki w zakresie podatków). 


\section{Fundusz Nsparcia Kultury jako wsparcie reaktywne}

Z jednej strony sektor kreatywny pozycjonuje się od wielu lat jako przemysł, pokazując statystyki wzrostu zatrudnienia, wzrostu gospodarczego itp. [Oakley, Banks 2020; O’Connor 2020], jako katalizator kreatywności w gospodarce. Z drugiej - zwłaszcza tradycyjnie rozumiane obszary działalności kulturalnej - prezentują się jako system wymagający wsparcia publicznego, przywołując argumenty znane w ekonomice kultury pod nazwą choroby Baumola (tj. postęp technologiczny w przypadku twórczości artystycznej nie wpływa na zwiększenie wydajności) [Baumol, Bowen 1966]. Ta dychotomiczna cecha całego sektora kreatywnego (w szczególności sztuk performatywnych) i rozdarcie między przemysłowym charakterem tej branży a jej charakterem publicznym znacząco utrudnia zaprojektowanie odpowiedniego programu wsparcia dla tej branży [Banks, O'Connor 2020].

Fundusz Wsparcia Kultury jest funduszem o charakterze reaktywnym. Reaktywność wsparcia rozumiana jest tu jako reakcja decydentów na problemy, które już wystąpiły. Nie są to nowe, nieznane wcześniej sposoby budowania mechanizmów pomocowych w kulturze. Jeśli założyć, że finansowe wsparcie o charakterze reaktywnym umożliwia ochronę działań zrealizowanych, wówczas do tej grupy zaliczyć można na przykład preferencje podatkowe, które można zastosować w momencie finalizacji danego działania.

Pandemia koronawirusa wywołała jednak potrzebę objęcia wsparciem reaktywnym wielu dotkniętych skutkami pandemii branż, w tym przemysłów kreatywnych. Instrumenty wsparcia zaproponowane przez decydenta publicznego w reakcji na pandemię obejmowały wiele instrumentów skierowanych do MŚP. Fundusz Wsparcia Kultury był skierowany do podmiotów działających w sektorze kultury i przemysłach kreatywnych, które obejmowały usługi wspomagające tę działalność przez organizacje zaplecza technicznego (scenotechnika).

\subsection{Dobór kryteriów w reaktywnym mechanizmie wsparcia}

Kryteria oceny stanowią podstawę procesu mającego na celu zbudowanie rzetelnej i racjonalnej procedury oceny wniosków składanych w ramach mechanizmów wsparcia ze środków publicznych. Badania przychylają się do opinii, że dobór kryteriów powinien być jak najbardziej precyzyjny, ponieważ wzmacnia to rzetelność oceny grantu oraz ogranicza wpływ subiektywnych przekonań osób dokonujących oszacowania wniosku [Abdoul i in. 2012].

Proces ewaluacji projektów finansowanych ze środków publicznych jest zjawiskiem bardzo złożonym. Na tę złożoność składają się między innymi [Drobniak 2005]:

1. Dobór sposobu pomiaru wieloaspektowych efektów przedsięwzięć w kulturze, co jest podstawową trudnością w ocenie produkcji twórczej. Pewnego rodzaju 
kluczem w skutecznym procesie oceny projektów jest rzetelne i wszechstronne rozpoznanie jej metod i narzędzi biorących pod uwagę specyfikę sektora kultury, w tym różnorodność ich wyników, efektywność z punktu widzenia społeczno-ekonomicznego, oddziaływanie projektów na wyróżnione grupy społeczne, czy też wpływ na czynniki rozwoju lokalnego.

2. Wymóg stworzenia przejrzystych podstaw dla rekomendacji na etapie podejmowania decyzji o ostatecznej alokacji zasobów.

Trafność kryteriów oceny wniosków grantowych jest ponadto istotna ze względu na zgodność celów strategicznych polityki kulturalnej z realizowanymi projektami [Langfeldt i in. 2019]. Ważna wydaje się ponadto ocena jakości wybranych projektów grantowych pod względem ich innowacyjności i różnorodności. Nadmierna koncentracja kryteriów konkursu grantowego na jednym aspekcie czy zagadnieniu (uniform assessment criteria) [Aagaard 2019] może działać hamująco na innowacyjność czy interdyscyplinarność projektów i w efekcie prowadzi do nadpodaży homogenicznych projektów. Literatura poświęcona doborowi kryteriów oceny wniosków rzadko koncentruje się na analizie trafności kryteriów konkursów grantowych. To jednak bardzo ważny obszar ze względu na legitymizację publicznego mechanizmu alokowania środków finansowych oraz na ewentualną próbę poprawy przejrzystości i jakości kryteriów oceny wniosków grantowych [Arensbergen, Besselaar 2012].

W praktyce wnioski grantowe są poddawane ocenie formalnej (I etap), ocenie wewnętrznych i zewnętrznych ekspertów (etap II - w formie oceny samodzielnej lub panelu ekspertów) oraz ocenie komisji weryfikującej jej adekwatność. Samodzielna ocena ekspercka (peer review) jest krytykowana ze względu na powstające rozbieżności co do postrzegania wniosku przez eksperta [Abdoul i in. 2012], co jest głównie powodowane przez wysoki poziom subiektywizmu. Proces oceny wniosków przez panele eksperckie również cechuje niedoskonałość wyrażająca się w dążeniu do kompromisu (consensus building) oraz społecznej kontekstualizacji decyzji (obiektywizacja powodów przyznania grantu) [Lewandowska, Smolarska 2020]. Ważną przeszkodą w formułowaniu rzetelnych kryteriów oceny wniosków jest ponadto możliwość wystąpienia konfliktu interesów [Abdoul i in. 2012].

Problemem w reaktywnych schematach wsparcia finansowego jest zbudowanie kryteriów wsparcia zgodnie z logiką, że pomoc skierowana jest do podmiotów, które określone działania już zrealizowały. „Ograniczoność zasobów sprawia, że budowane są kryteria racjonalności dla wydatkowania zasobów w ramach określonych programów polityki" [Zybała 2017, s. 76]. Zatem nawet forma wsparcia reaktywnego nie omija systemu selektywnego, w którym zbiór kryteriów pozwala na formułowanie listy działań rekomendowanych do wsparcia. FWK jest mechanizmem rekompensat „z tytułu utraconych przychodów w okresie od dnia 12 marca do 31 grudnia 2020 roku (par. 5 Rozp. Rady Ministrów z dnia 30 września 2020). Rekompensata jest tu rozumiana jako „wypłata sumy pieniężnej bądź przyznanie innych korzyści dla zrekompensowania doznanej szkody, która nie może być w sposób bezpośredni 
naprawiona" [Jasudowicz 2019, s. 65]. Stąd i naczelnym zamierzeniem FWK było przyznanie środków finansowych tym podmiotom, które w wyniku pandemii koronawirusa doświadczyły ekonomicznych trudności w zakresie utrzymania ciągłości funkcjonowania.

We wszystkich schematach wsparcia działań ze środków publicznych, w tym również w przypadku wsparcia reaktywnego zachodzi pytanie o efektywność wykorzystania zasobów. To, co przychodzi łatwiej w ekonomii, w kulturalnej polityce sektorowej staje się bardziej skomplikowane. Dlatego też w przypadku FWK dokonano wyboru dwóch kluczowych kryteriów: 1) spadek przychodów z działalności kulturalnej w dziedzinie teatru, muzyki, tańca, w tym usług wspomagających tę działalność poprzez organizację zaplecza technicznego, 2) liczba zatrudnionych osób na dzień złożenia wniosku w stosunku do stanu zatrudnienia na dzień 31 grudnia 2019 roku. Te dwie miary stały się główną osią kryterialnego spojrzenia na wnioskujące podmioty, pokazując intencję gestora środków publicznych.

\section{Metodologia badán}

Bogactwo badań poświęconych zmianom wywołanym przez pandemię koronawirusa w przemysłach kreatywnych jest dowodem na istotność tego zagadnienia. Sam Fundusz Wsparcia Kultury jako instrument rekompensujący straty w branży stał się interesującym przyczynkiem do szerokich dyskusji na temat mechanizmów udzielania wsparcia. Nagłość pandemii, jak i jej nieprzewidywalne skutki są elementami, które wywierają potężny wpływ na funkcjonowanie kultury, wzbudzając tym samym wszechstronną uwagę badaczy. $Z$ dużym natężeniem projektuje się wizje przyszłości kultury i przemysłów kreatywnych, jednak jest to zadanie wysoce złożone, ponieważ niepewności nie dotyczą samej kultury - ogrom obaw czy niewiedzy sięga wymiaru gospodarczego, medycznego czy społecznego. Z tego względu w artykule skupiamy się na analizie niezwykle specyficznego instrumentu wsparcia o charakterze reaktywnym - Funduszu Wsparcia Kultury. Zastosowanym narzędziem jest w pierwszej kolejności analiza danych zastanych. Podejmujemy wyzwanie kompleksowego spojrzenia na publikowane raporty i informacje zamieszczane na portalach branżowych poświęcone tej tematyce, również przyglądamy się: Kryteriom oceny wniosków w FWK, Instrukcji wypełniania wniosku, Regulaminowi FWK. Analiza danych zastanych pozwoliła na ukształtowanie obrazu aktualnej kondycji branży kreatywnej, ze szczególnym uwzględnieniem scenotechniki. Dramaturgię sytuacji tego obszaru podkreślono w indywidualnych wywiadach pogłębionych z czterema beneficjentami Funduszu Wsparcia Kultury, które zostały przeprowadzone między 30 grudnia 2020 a 13 stycznia 2021 roku. Był to szczególny czas ze względu na przełom roku, lecz przede wszystkim okres rozliczeń rekompensat udzielonych w ramach FWK (środki musiały zostać wydane do 31 grudnia 2020 i rozliczone 
do 15 stycznia 2021 roku). Głównym celem wywiadów była analiza FWK zarówno z perspektywy projektodawców, jak i z punktu widzenia odbiorców tego wsparcia. Wnioski zostały zbudowane według trzech wymiarów analizy: wymiaru proceduralnego, merytorycznego oraz kontekstualnego. Taki schemat prezentacji wyników badań był naszym zdaniem najbardziej obrazowym rozwiązaniem, pozwalającym na wielowymiarowe spojrzenie na konstrukcję FWK.

\subsection{Charakterystyka badanych podmiotów}

R e sp on de nt 1 reprezentuje dwie firmy z branży scenotechnicznej, jedna zajmuje się wsparciem organizacji wydarzeń związanych z szeroko rozumianym rynkiem muzycznym, a druga produkuje wydarzenia kulturalne, na przykład spektakle multimedialne (jednoosobowa działalność gospodarcza oraz spółka cywilna).

Respondent 2 zajmuje się realizacją przedstawień teatralnych głównie o charakterze rozrywkowym, funkcjonując na zasadzie wyjazdowej.

Respondent 3 prowadzi jednoosobową działalność gospodarczą w zakresie wspomagania wystawiania przedstawień artystycznych.

Respondent 4 prowadzi jednoosobową działalność gospodarczą w zakresie wspomagania wystawiania przedstawień artystycznych, w szczególności koncertów i wydarzeń muzycznych. Stały podwykonawca klubów muzycznych i instytucji kultury, a także dużej firmy koncertowej.

Tabela 1. Zestawienie respondentów wywiadów - beneficjentów FWK

\begin{tabular}{|l|l|l|l|l|}
\hline $\begin{array}{c}\text { Nr respon- } \\
\text { denta }\end{array}$ & \multicolumn{1}{|c|}{$\begin{array}{c}\text { Stanowisko i typ } \\
\text { organizacji }\end{array}$} & $\begin{array}{l}\text { Obszar działa- } \\
\text { nia organizacji }\end{array}$ & $\begin{array}{l}\text { Wysokość otrzy- } \\
\text { manego wsparcia }\end{array}$ & $\begin{array}{l}\text { Data i godzina } \\
\text { przeprowadzo- } \\
\text { nego wywiadu }\end{array}$ \\
\hline \hline Respondent 1 & $\begin{array}{l}\text { właścicielka jednoosobowej } \\
\text { działalności i partner } \\
\text { w spółce cywilnej }\end{array}$ & scenotechnika & $\begin{array}{l}\text { Ok. 50 tys. zł } \\
\text { oraz } \\
\text { ok. } 500 \text { tys. zł }\end{array}$ & $\begin{array}{l}30.12 .2020, \\
\text { g. 14.00 }\end{array}$ \\
\hline Respondent 2 & $\begin{array}{l}\text { reżyser, dyrektor teatru VIS } \\
\text { a VIS - udziałowiec sp. z o.o. }\end{array}$ & teatr & Ok. 50 tys. & $\begin{array}{l}30.12 .2020, \\
\text { g. 21.00 }\end{array}$ \\
\hline Respondent 3 & $\begin{array}{l}\text { właściciel jednoosobowej } \\
\text { działalności }\end{array}$ & scenotechnika & $\begin{array}{l}\text { Kilkanaście } \\
\text { tysięcy złotych }\end{array}$ & $\begin{array}{l}7.01 .2021, \\
\text { g. 11.25 }\end{array}$ \\
\hline Respondent 4 & $\begin{array}{l}\text { właściciel jednoosobowej } \\
\text { działalności }\end{array}$ & $\begin{array}{l}\text { scenotechnika - } \\
\text { nagłośnienie } \\
\text { i realizacja } \\
\text { dźwięku }\end{array}$ & $\begin{array}{l}\text { Kilkanaście } \\
\text { tysięcy złotych }\end{array}$ & $\begin{array}{l}13.01 .2021, \\
\text { g. 19.00 }\end{array}$ \\
\hline
\end{tabular}

Źródło: opracowanie własne. 


\section{Fundusz Nsparcia Kultury jako mechanizm rekompensat}

Fundusz Wsparcia Kultury to instrument pomocy finansowej dla sektora kultury powołany na mocy Rozporządzenia Rady Ministrów z dnia 30 września 2020 roku w sprawie wsparcia finansowego jednostek prowadzących działalność kulturalną w dziedzinie teatru, muzyki lub tańca. Rozporządzenie określa zasady rozdziału i przekazywania wsparcia z państwowego funduszu celowego „Funduszu Przeciwdziałania COVID-19”, utworzonego na podstawie art. 65 Ustawy z dnia 31 marca 2020 roku o zmianie ustawy o szczególnych rozwiązaniach, związanych z zapobieganiem, przeciwdziałaniem i zwalczaniem COVID-19, innych chorób zakaźnych oraz wywołanych nimi sytuacji kryzysowych, i niektórych innych ustaw.

Operatorami FWK z ramienia Ministerstwa Kultury i Dziedzictwa Narodowego byli Instytut Teatralny im. Zbigniewa Raszewskiego oraz Instytut Muzyki i Tańca. Założenia finansowe FWK zostały wypracowane przez działający przy Instytucie Teatralnym zespół ekspercki ds. sytuacji teatru w czasie pandemii, ekspertów Ministerstwa Kultury i Dziedzictwa Narodowego oraz przedstawicieli środowisk muzycznych i tanecznych.

O pomoc finansową w ramach 400-milionowego budżetu Funduszu Wsparcia Kultury ubiegało się 2246 podmiotów prowadzących działalność kulturalną w obszarze teatru, muzyki lub tańca. Ocenie merytorycznej poddano 2064 prawidłowo wypełnione oraz złożone wnioski i te wnioski zostały zakwalifikowane do wsparcia (I runda oceny) [Instytut Teatralny www]. Wśród ostatecznych 2064 beneficjentów znalazły się następujące podmioty [Pawlak 2020]:

Tabela 2. Kwoty wsparcia i liczba beneficjentów FWK

\begin{tabular}{|l|c|c|c|}
\hline & $\begin{array}{c}\text { Liczba } \\
\text { beneficjentów }\end{array}$ & $\begin{array}{c}\text { Średnia kwota } \\
\text { wsparcia }\end{array}$ & $\begin{array}{c}\text { Lączna kwota } \\
\text { wsparcia }\end{array}$ \\
\hline \hline Samorządowe instytucje artystyczne & 144 & 657 tys. zł & $94716434 \mathrm{zł}$ \\
\hline Organizacje pozarządowe & 306 & 126 tys. zł & $38578661 \mathrm{zł}$ \\
\hline Przedsiębiorcy & 448 & 203 tys. zł & $90959964 \mathrm{zł}$ \\
\hline $\begin{array}{l}\text { Firmy świadczące usługi zaplecza } \\
\text { scenotechnicznego }\end{array}$ & 1166 & 150 tys. zł & $175235109 \mathrm{zł}$ \\
\hline
\end{tabular}

Źródło: Fundusz Wsparcia Kultury, MKiDN, https://www.gov.pl/web/kultura/fundusz-wsparcia-kultury/ [odczyt: 12.01.2021]. 


\subsection{Wymiar proceduralny}

Utworzenie Funduszu rezonowało z potrzebą natychmiastowej reakcji władz publicznych, głównie Ministerstwa KiDN na negatywne skutki pandemii koronawirusa, które dotknęły instytucje artystyczne. Formuła procedowania wniosków nie była oparta na zasadzie oceny projektów proponowanych do realizacji w obszarze kultury - jak ogłoszony w kwietniu 2020 roku program stypendialny MKiDN „Kultura w sieci”, finansujący zmiany formy upowszechniania działalności twórczej. W przypadku FWK celem było przyznanie bezzwrotnej pomocy, mającej zapewnić ciągłość działalności artystycznej i utrzymanie miejsc pracy w sektorze kultury. O rekompensaty z tytułu utraconych przychodów w okresie od dnia 12 marca 2020 do 31 grudnia 2020 roku (obliczonych na podstawie danych $\mathrm{z}$ analogicznego okresu w roku 2019) mogły wnioskować następujące podmioty:

- samorządowe instytucje artystyczne, do $40 \%$ przychodów netto z działalności statutowej oraz dodatkowej;

- organizacje pozarządowe prowadzące działalność w dziedzinie teatru, muzyki lub tańca - do 50\% przychodów netto ze sprzedaży usług związanych z działalnością kulturalną;

- przedsiębiorcy prowadzący działalność gospodarczą w dziedzinie teatru, muzyki lub tańca, w tym usług wspomagających tę działalność przez organizację zaplecza technicznego - do $50 \%$ przychodów netto ze sprzedaży usług związanych z działalnością kulturalną.

Wnioski były przyjmowane za pomocą generatora wniosków Witkac.pl, który automatycznie weryfikował oferty oraz sprawozdania pod kątem poprawności formalnej i rachunkowej, a członkowie komisji konkursowych oceniali oferty online.

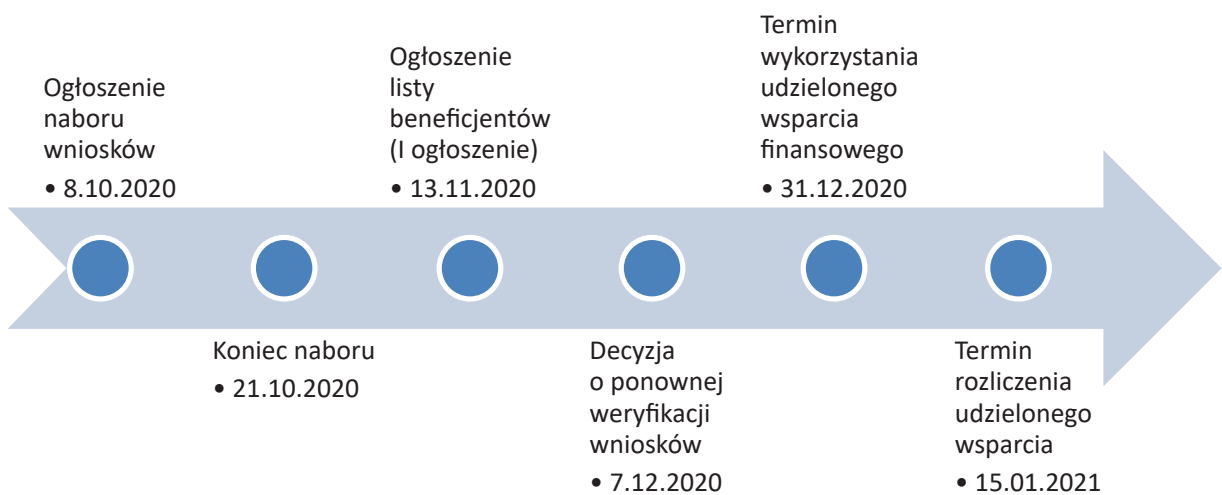

Rycina 1. Przebieg wydarzeń - oś czasu

Źródło: opracowanie własne. 
Mimo krótkich terminów między ogłoszeniem naboru a terminem zamknięcia naboru respondenci wcześniej wiedzieli o możliwości wnioskowania. Głównym źródłem ich wiedzy były strony MKiDN, inne strony rządowe oraz informacje branżowe. Respondenci często przygotowywali wnioski w ostatnim dniu nabo$\mathrm{ru}, \mathrm{co} \mathrm{z}$ jednej strony nie stanowiło problemu, ponieważ w opinii respondentów sam formularz był prosty do wypełnienia, jednak z drugiej strony nie było już możliwości wyjaśnienia ewentualnych wątpliwości z pracownikami operatorów FWK. Dodatkowo na stronach operatorów FWK dostępne były instrukcje wypełniania wniosku. Wszyscy respondenci bardzo dobrze oceniali proces komunikacji z pracownikami Instytutu Teatralnego lub Instytutu Muzyki i Tańca obsługującymi beneficjentów.

\section{Proces aplikacyjny}

Wszyscy respondenci zgodnie przyznają, że wniosek do FWK był prosty i przystępny. Część wniosku wypełniła się automatycznie, a zawierał on jedynie dwie pozycje opisowe: wpływ na społeczność lokalną i opis działalności firmy. Wniosek nie wymagał określenia wskaźników projektowych, nie wymagał również potwierdzenia podpisem kwalifikowanym czy certyfikacji. Również platforma Witkac, za pomocą której wypełniano wnioski, oceniana była jako intuicyjna.

Respondent 1: Tu wniosek był przyjazny. Uproszczony. Dlaczego: bo to było dla kultury, która nie zawsze idzie z biznesem pod rękę. Artyści nie mają księgowych, kancelarii prawnych.

Respondent 4: Jedna była fajna rzecz w tym wniosku. Wpisywało się wszystko, co się robiło w 2019, a później to, co się robiło w 2020 i program na podstawie różnicy faktur obliczał, jaką mam stratę, i to unaoczniało faktycznie, jaką kto ma stratę!

Pojawiły się jednak głosy, że „Instrukcja do wniosku niekoniecznie była prosta, głównie pod względem szczegółowości i jednoznaczności” (Respondent 1). Trudność polegała przede wszystkim na niejednoznaczności informacji na temat kosztów kwalifikowanych. W przypadku podmiotów mających wcześniejsze doświadczenie w dostosowywaniu kosztów kwalifikowanych do wymogów danego wniosku, na przykład unijnego, tak ogólne zarysowanie warunków wsparcia powodowało duże sprzeczności.

Respondent 1: Znakomitym przykładem są leasingi. Część osób zakwalifikowała leasingi, a część nie, bo takie sprzeczne informacje pozyskali. W Instrukcji nie ma definicji, informacji, co się pod danym kosztem kryje. Nie ma informacji, czy mamy klasyfikować koszty netto czy brutto. Co z podatkiem? 
Wątpliwości na etapie konstruowania wniosku było jednak wiele. Często wskazywaną niewiadomą był sposób przydzielania wnioskodawcy do Instytutu będącego operatorem FWK (Instytut Muzyki i Tańca lub Instytut Teatralny). Mimo wskazania we wniosku jednego z Instytutów, docelowo mogła nastąpić zmiana (Respondent 1).

Respondent 1: Wniosek dawał duże pole do interpretacji. Pytanie, na ile ta interpretacja jest zgodna z regułami. My się o tym dowiemy dopiero na etapie rozliczania tych wniosków. Brakowało szczegółowego wyjaśnienia pewnych terminów używanych w instrukcji, było to zbyt dowolne do interpretowania.

Respondent 4: Regulamin tej dotacji jest napisany w tak zły sposób, że nie wiadomo, jak to rozliczyć. (...) W tym regulaminie połowy rzeczy nie ma. Tu jest problem.

Respondent 4: Ale nie jest określone w regulaminie, co to jest wydarzenie artystyczne i jaka faktura pod to podlega. (...) Jak ja wypożyczam sprzęt, to też pożyczam sprzęt na imprezę czy koncert. Można uznać, że to jest impreza kulturalna, ale pytanie, czy ona jest kulturalna? Pytanie, czy nie powinienem zrobić czegoś dla instytucji kultury. Koncert prywatny też... Ja robię usługi wspomagające wydarzenia artystyczne, to wpisałem wszystkie, bo innych faktur nie wystawiam.

Respondent 4: Pytania i odpowiedzi były niejednoznaczne i nie pokrywały się z tym, co było $\mathrm{w}$ regulaminie. Bo w pytaniach i odpowiedziach jest więcej, dziesięć razy tyle więcej, co w samym regulaminie. Dziwne trochę. Sam fakt, jak oni zmieniali to, nie było w regulaminie, jak się za pierwszym składało wniosek ani słowa o środkach trwałych - czy można kupić bądź nie. A potem, jak zawiesili i wstrzymali te dotacje, i odnowili, to nagle w pytaniach i odpowiedziach pojawiło się, że nie można kupić środków trwałych, podczas gdy ludziom przechodziły takie wnioski. Gdzie niektórzy dostali już, i przeszedł im ten wniosek ze środkami trwałymi, więc dla mnie to nie jest logiczne. Dezinformacja po prostu!

Respondent 4: Przygotowanie pierwszego wniosku zajęło ze 2-3 godziny, a kolejna wersja ze 3 i więcej godzin, bo musiałem zacząć czytać te pytania i odpowiedzi i zacząłem się w tym gubić. Natomiast jak dostałem te pieniądze, to spędziłem już dziesięć razy tyle, żeby to rozliczyć, a jeszcze tego nie zrobiłem...

\section{Reweryfikacja wniosków}

Ogłoszona w listopadzie 2020 roku lista beneficjentów FWK wywołała duży szum medialny, której towarzyszyły dyskusje na temat zasadności wsparcia. 
Respondent 2: Nie rozumiemy, czemu społeczeństwo nas tak nienawidzi. Rozmawiałem o tym z moimi artystami, byliśmy bardzo rozżaleni, bo ludzie przychodzą na spektakle, koncerty, koncerty oglądają, przychodzą na świąteczne czy sylwestrowe, w Ostródzie, w Zakopanem czy gdziekolwiek. Nie zdają sobie sprawy, że my ich karmimy dobrem i pięknem. Ja to podkreślam, DOBREM I PIĘKNEM. Dzięki nam mają szansę w tym smutnym, szarym, pandemicznym świecie obcować z dobrem i pięknem. Ja byłem załamany po tym, co się stało, zresztą po tym wszystkim oni zrobili taką reweryfikację i nam obcięli przecież tą refundację.

Precedens ten stał się momentem zwrotnym, ponieważ decyzją Ministra KiDN ogłoszono proces powtórnej weryfikacji wniosków. Kryteria towarzyszące temu procesowi nie zostały upublicznione. Respondenci jako beneficjenci FWK otrzymali $\mathrm{w}$ korespondencji indywidualnej informację o zweryfikowanej kwocie wsparcia, która już nie była podawana do publicznej wiadomości. Aktualizacja kwot wsparcia oznaczała z reguły ich obniżenie, jednak żaden z respondentów nie uzyskał uzasadnienia merytorycznego takiej decyzji. Prawdopodobnie obniżenie zatwierdzonych w listopadzie dotacji może być wywołane koniecznością wsparcia spółek cywilnych, o których zapomniano w pierwszym rozdaniu.

Respondent 1: Jedna z izb skupiających artystów złożyła odwołanie do dysponenta tych środków, że spółki cywilne też powinny mieć prawo i możliwość korzystania, bo gros artystów prowadzi takie firmy. I to zostało odblokowane.

Respondent 1: Firma - jednoosobowa działalność nie dostała tych 600 tys., wsparcie zostało ucięte do ok. 518 tys. Bez żadnego komentarza. Dostaliśmy umowę na taką kwotę. Druga firma - spółka - aplikowaliśmy o podobną kwotę, otrzymaliśmy 1/10 tej kwoty. Dostaliśmy informację 2-3 dni przed świętami. 22 grudnia zadzwonił do mnie pracownik Instytutu, że po raz kolejny mamy poprawić wniosek. Bo kwota została przyznana, ale ona różni się od kwoty wnioskowanej i czy możemy to zmienić szybko. Zapytałam, co to znaczy, że się trochę różni. Usłyszałam, że dostaliśmy 48 tys. Więc mówię: Nie, chyba 480 tys.? Rozmówca mówi: Nie, 48 tys. Pytam, jaka jest tego podstawa. Rozmówca: No... Nie ma. To jest decyzja ministerstwa. Były komisje eksperckie i tak oceniły. Pytam więc, dlaczego firma, która świadczy wyspecjalizowane usługi, dostaje 1/10 wnioskowanej kwoty?

Respondent 1: Przejrzystość oceny nie istnieje. Nie mamy informacji, jaką uzyskaliśmy punktację. Dlatego nie rozumiem decyzji o przyznaniu tak małej kwoty na drugą działalność. O 518 tys. mogliśmy ubiegać się w przypadku spółki cywilnej. Po odliczeniu wszystkich pomocy. To maksymalny pułap. Więc ta decyzja jest uznaniowa.

Respondent 2: Jak ktoś dostał milion i mu obcięli 100 tys., to nawet tego nie poczuł. Myśmy dostali 63778 zł, a po weryfikacji otrzymaliśmy 54 849, czyli prawie dycha mniej. Przy tego rzędu dofinansowaniu to dla nas istotna różnica. 
Respondent 3: Z moich obliczeń na podstawie wytycznych powinno wyjść 25 tys. Finalnie dostałem 15 tys.

\subsection{Wymiar merytoryczny}

Kryteria algorytmu przyznającego wsparcie były zbudowane na podstawie dwóch grup kryteriów:

- kryteria formalne, których niespełnienie skutkowało odrzuceniem wniosku;

- kryteria merytoryczne, których spełnienie oceniano na podstawie deklaracji wnioskodawcy. Kryteria merytoryczne podlegały ocenie punktowej ważonej, sformułowanej odrębnie dla samorządowych instytucji kultury, organizacji pozarządowych oraz przedsiębiorstw.

Wysokość dotacji zależała od spadku przychodów w porównaniu rok do roku oraz od wnioskowanej kwoty. Aż 81 podmiotów otrzymało taką samą kwotę 664500 zł. Wśród 172 podmiotów, które otrzymały najwyższe wsparcie, jest 47 instytucji kultury (27,33\%), 11 organizacji pozarządowych (6,40\%), 53 spółki prawa handlowego $(30,81 \%)$ i aż 61 podmiotów prowadzących jednoosobową działalność gospodarczą $(35,47 \%)$ [Fundusz Wsparcia Kultury].

Ze względu na kontrowersje związane z przyznaniem wsparcia złożone wnioski zostały poddane powtórnej ocenie w II rundzie. Jej celem było potwierdzenie kwalifikowalności kosztów i zgodności oświadczeń składanych przez beneficjentów $\mathrm{z}$ ich faktycznym profilem działalności. W rezultacie potwierdzono, że rekompensaty przydzielono podmiotom uprawnionym, prowadzącym działalność w obszarze kultury i produkcji artystycznej. Beneficjenci funduszu są zobligowani do rozliczenia się z zadeklarowanych kosztów kwalifikowalnych i przypisanych im we wniosku wydatków do 15 stycznia 2021 roku.

\section{Przygotowanie kosztorysu i wydatkowanie środków}

Rozmówcy ujmowali bardzo różne koszty kwalifikujące się do wsparcia w ramach FWK. Przeważnie były to koszty stałe lub honoraria dla współpracowników zatrudnianych na umowy cywilnoprawne. Było to zależne od specyfiki działalności wnioskujących podmiotów i wielkości kosztów ponoszonych na działalność operacyjną.

Zarówno w wywiadach, jak i w opiniach medialnych wokół listy beneficjentów FWK dało się odczuć duży poziom niezrozumienia intencji tego mechanizmu wsparcia. Z jednej strony mechanizm bowiem dopuszczał wsparcie wynikające z wielkości spadku przychodu w 2020 w porównaniu z okresem od marca 2019 do grudnia 
2019 roku. Taka elastyczność umożliwiała uwzględnienie w kosztorysie kosztów stałych, ponoszonych przez część firm w tym okresie, takich jak wynagrodzenia pracowników na umowę o pracę czy koszty leasingu urządzeń, koszty magazynów itp. Z drugiej strony podmioty, których główne koszty wynikają z zawierania umów cywilnoprawnych z podwykonawcami, miały trudność w wykazaniu kosztów w roku 2020, ponieważ w tym okresie umów nie zawarły ze względu na brak lub ograniczoną działalność. Te firmy nie miały zatem możliwości uwzględnienia w kosztorysie umów na przykład $\mathrm{z}$ aktorami, które nie zostały zawarte choćby ze względu na brak możliwości wystawienia spektakli.

Zatem refundacyjny, zapomogowy charakter FWK odnosił się jedynie do części beneficjentów. Niektóre podmioty podejmowały wyzwanie realizacji projektów w obszarze kultury w terminie do końca 2020 roku, by otrzymać wsparcie, które dla wielu z nich było ważnym źródłem utrzymania. Dla tych podmiotów wsparcie FWK miało więc charakter quasi-konkursowy.

Respondent 2: Paradoks tego programu polega na tym, że jest to refundacja, a nie dotacja, ale pożądane tam jest stworzenie nowych projektów... Bo tam regulamin nie przewiduje antydatowania umów. Umowy muszą być zawarte do końca roku. - Ale umowy mogą być zawarte od marca 2020 ... - Ale to się wyklucza, jest błąd logiczny. Jak ja mogę zawrzeć umowę z aktorem na wykonanie roli aktorskiej, której on nie wykonał? My wnioskowaliśmy tylko o honoraria. Dla mnie to dobrze, bo mnie to napędziło twórczo i artystycznie, bo musiałem powymyślać różne projekty, by wszystko do 31 grudnia było dobrze... I wszyscy się cieszą, bo kupa ludzi ma pracę, jakieś pieniądze sobie zarobią.

Respondent 2: Bardzo istotne jest to, by podkreślać, że to jest refundacja algorytmiczna, a nie dotacja. Bo to jest refundacja do 50\% przychodu za 2019 rok, a nie dochodu. Rekompensata utraconego przychodu w wyniku pandemii.

Respondent 2: Różnica pomiędzy FWK a Kulturą odporną z UMK polegała na Jury, które oceniało wartość artystyczną proponowanego projektu.

Rozmówcy zgodnie przyznają, że nie mieli problemów z wydatkowaniem środków pochodzących z rekompensaty w okresie do 31 grudnia 2020 grudnia. Jednak wyraźne były różnice zarówno w podejściu do konstruowania budżetu, jak i do jego wydatkowania.

Rozmówca 1: Nie mam problemów z wydatkowaniem środków. Wydatki można odliczać od marca 2020 do grudnia 2020. W przypadku jednoosobowej działalności kwota miesięczna leasingu i wynajmu magazynu i pensji przekracza koszt otrzymanej pomocy. Więc wystarczy, że przedstawię fakturę do rozliczenia $\mathrm{z}$ jednego miesiąca. W przypadku spółki cywilnej to 1/7 kosztów miesięcznych mojej firmy. 
Respondent 3: Część pieniędzy zainwestowałem w sprzęt, którego bym nie kupił, nie mając finansowania. Częściowo dałem na pracownika. Częściowo te wydatki były pokryciem realnym strat, a częściowo na przyszłość.

Respondent 4: Zakupiłem sprzęt, który pozwoli mi się przekwalifikować. (...) kupiłem uszy monitory (bezprzewodowe odbiornik i słuchawki) i wpisałem to w koszta, ale nikt nie jest w stanie powiedzieć, łącznie ze skarbówką, czy ja powinienem zwrócić podatek, który sobie odliczyłem, czy nie. Nikt tego nie wie. W regulaminie nie ma nic. W pytaniach na stronie jest napisane, że oni nie wiedzą i trzeba się zgłosić do skarbówki. Ja mam czas do 15 stycznia i dzisiaj chodzę jak na szpilkach cały dzień. (...) Od 9 rano biegam po urzędach, staram się czegoś dowiedzieć, dzwonię, chodzę po urzędach, byłem u księgowej, poprawiam faktury, wpisuję te wszystkie rzeczy.

\section{Efekty FWK}

Respondenci zgodnie - mimo bardzo różnej skali wsparcia - podkreślali, że każda pomoc jest ważna, i cieszą się z przyznanych środków, ponieważ zapewniają im one przetrwanie, a poza tym dają możliwość rozwoju na innych polach.

Respondent 2: Mechanizmy wsparcia pozwoliły w fundamentalny sposób przeżyć i podtrzymać sens tej pracy, a nie zatrudniać się w Biedronce albo Poczcie Polskiej. Mechanizm pozwolił utrzymać zaplecze i zasoby niezbędne do zapewnienia ciągłości działania kultury.

Respondent 1: To jeden z elementów, które pomogą nam przetrwać. Możemy się skupić na rozwijaniu firmy, a nie na ratowaniu jej. To różnica. Przedsiębiorca to nie jest podmiot prowadzący działalność tylko wtedy, gdy jest dobrze. Bierze na klatę negatywne skutki tego, co się dzieje na świecie. Zredukowaliśmy nasze koszty życia, zrezygnowaliśmy z biura, zmieniliśmy mieszkanie na biuro. Pandemia nauczyła nas rozmawiać z instytucjami finansowymi. Wiele zależy od nastawienia i oczekiwań. Pandemia uczy pokory.

Respondent 4: W porządku i fajnie, że ludzie mogli sobie odliczyć stratę, którą ponieśli z powodu tego, że dane wydarzenie się po prostu nie odbyło. I dla mnie też, że ja mogę sobie rozszerzyć wachlarz usług.

\subsection{Wymiar kontekstowy}

MKiDN podkreślało, że Fundusz Wsparcia Kultury nie jest projektem wartościującym działania kulturalne, których pomysłodawcy objęci zostali wsparciem. Jakość 
nie była tu rozumiana elitarnie przez pryzmat rangi danego wydarzenia czy projektu, jego poziomu artystycznego, dotychczasowych osiągnięć itp. Celem nadrzędnym FWK był egalitarny i utylitarny charakter wsparcia nakierowany na podtrzymanie sektora kultury i ratowanie miejsc pracy. W informacjach MKiDN mocno podkreślano cele ekonomiczne FWK, postrzegając ten mechanizm jako koło zamachowe gospodarki poprzez aktywizację szeroko rozumianego sektora kreatywnego.

By ujednolicić mechanizm przyznania rekompensat, przyjęto rozwiązanie polegające na wskazaniu maksymalnego procentowego poziomu pomocy oraz ocenę ekspertów. Wysokość wsparcia finansowego miała być też pomniejszona o wcześniej otrzymaną pomoc z funduszy przeciwdziałania koronawirusowi, aby uniknąć podwójnego finansowania wydatków ze środków publicznych.

W tak pomyślanym rozwiązaniu pomocowym liczyła się przede wszystkim sprawność, rozumiana jako szybkie podejmowanie decyzji o przyznaniu wsparcia wnioskującym podmiotom (od ogłoszenia naboru do zamknięcia naboru: $13 \mathrm{dni}$, od zamknięcia naboru do ogłoszenia wyników po I rundzie - 23 dni). Autorzy tego mechanizmu założyli przyznanie pomocy na podstawie deklaracji. Stąd budzącym emocje elementem wnioskowania o wsparcie było ogólne zobowiązanie beneficjenta do kontynuacji prowadzonej przez niego działalności gospodarczej przynajmniej do momentu rozliczenia otrzymanego wsparcia. Kontrola rozliczenia przyznanych środków ma z kolei nastąpić ex post na próbie co najmniej 30\% losowo wybranych podmiotów, które muszą uwiarygodnić koszty kwalifikowalne dokumentacją (faktury, rachunki, utrzymanie miejsc pracy). Środki niewydatkowane $\mathrm{w}$ terminie lub niezgodnie $\mathrm{z}$ celami funduszu będą podlegały zwrotowi do budżetu państwa w całości lub części.

\section{Wnioskowanie o inne instrumenty wsparcia}

Rozmówcy reprezentują bardzo różne doświadczenie w aplikowaniu o granty - od beneficjentów dużych programów unijnych do podmiotów niebiorących udziału (lub okazjonalnie) w żadnych konkursach grantowych przed pandemią, ponieważ nie było to konieczne i gwarantowało niezależność działalności.

Rozmówca 2: Nie korzystaliśmy z dofinansowań, gdyż byliśmy niezależni, komercyjni. Bardzo sobie to ceniłem, gdyż to dawało wolność. Nie musiałem logotypów umieszczać, sugestii artystycznych uwzględniać.

Pandemia jest jednak czasem, w którym działalność gospodarcza podmiotów w obszarze kultury jest zamrażana, dlatego też wykładniczo wzrosło zainteresowanie udziałem w programach ogólnopolskich lub miejskich, umożliwiających pozyskanie wsparcia finansowego na podtrzymanie działalności. 
Respondent 2: Jako reżyser dostałem stypendium w ramach programu Kultura Odporna od Miasta Kraków, wykup dzieł w ramach Kultura Odporna też z miasta. Ministerstwo odpadło. Dostaliśmy mikropożyczkę bezzwrotną w ramach Grodzkiego Urzędu Pracy, ale nie w ramach Tarczy 6.0. I dla KBF w ramach partnerstwa dla muzyki zrobiliśmy trzy realizacje i to wszystko...

Respondent 1: Jesteśmy beneficjentem innych zapomóg, czyli PFR [Tarcza Finansowa Polskiego Funduszu Rozwoju - przyp. aut.], Urzędy Pracy, Małopolska Tarcza Antykryzysowa, korzystaliśmy ze wszystkich możliwych form wsparcia covidowych. Mamy duże doświadczenie w pozyskiwaniu środków.

Respondent 3: Tak, w ramach przeciwdziałania COVID-owi. Pożyczka jednorazowa 5 tys., świadczenie postojowe 2 razy, zwolnienie z ZUS na 3 miesiące. (...) Niestety moja działalność nie jest oparta tylko na działalności artystycznej.

Respondent 4: Jak kiedyś firmę zakładałem, to z dotacji z Urzędu Pracy. Jak się zaczęła pandemia, raz mi umorzyli ZUS. Jak była pożyczka, to też ją dostałem na pracownika, dokładnie to 30 tysięcy na pracownika było.

\section{Strategie radzenia sobie $z$ brakiem możliwości realizacji wydarzen w kulturze}

W wyniku wywiadów zidentyfikowano trzy główne strategie działania w warunkach ograniczeń wynikających z reżimu sanitarnego:

- przeniesienie działalności do Internetu,

Respondent 2: Teatrowi zależy na interaktywności przedstawień i bezpośrednim kontakcie z widzem. Kilka produkcji zostało opublikowanych w wersji online, jednak jakość i emocje towarzyszące takim spektaklom nie są tak wyraźne, jak w przypadku realizacji na prawdziwej scenie. Przedstawienia online są pozbawione zmysłowości, są „spłaszczone”, trudno jest odtworzyć wrażenia estetyczne w podobnym natężeniu, jak zapach czy kolor (...). Teraz będziemy przenosić kilka spektakli do Internetu (...), żeby się podtrzymać w świadomości, pokazać nowym osobom i nowym instytucjom.

- rozwijanie oferty komplementarnej,

Respondent 1: Pandemię dotychczas przetrwaliśmy w składzie niezmienionym, nie zwolniliśmy nikogo. Przeorganizowaliśmy się, uruchomiliśmy się na nowe rynki i usługi. Finansowo jest ta pandemia ciosem w plecy, bo firma się dobrze z roku na rok rozwijała, notowaliśmy 
wzrost obrotów średnio o 20-25\% co roku. Teraz mamy 1/5 tego, co mieliśmy w stosunku do roku 2019 (jednoosobowa działalność), a w spółce cywilnej - zanotujemy dużą stratę, nie uda się tego obronić.

Respondent 1: Nie jesteśmy się w stanie przebranżowić, bo jesteśmy zbyt wyspecjalizowani. 10 lat na rynku, w zasadzie 12 lat doświadczenia, sztab szkolonych ludzi, wiele milionów nakładów inwestycyjnych oraz wartości niematerialne: budowanie marki, jakość i zadowoleni klienci. To, co było możliwe - stworzyliśmy nowy produkt w oparciu o to, co dotychczas robiliśmy. Ten produkt będziemy wdrażać od 1 stycznia. To oferta komplementarna (konsorcjum 4 podmiotów).

Respondent 1: Firmy zaczęły ze sobą w trakcie pandemii współpracować. Branża, w której działamy, jest wąska. Firmy dotychczas ze sobą konkurowały, podbierając klientów. Pandemia zmieniła nastawienie. Zmieniły się ceny na rynku. Część firm, żeby przeżyć, zaczęła dumpingować ceny. My kilkakrotnie odmówiliśmy współpracy, słysząc 6-krotnie niższe stawki. Dużo jednak firm oferujących usługi komplementarne zawiązało formę kolektywu i wdrożyło nowy produkt. Ktoś daje technikę, ktoś wiedzę, miejsce. Wróciliśmy do tworzenia, poszukiwania, wymyślania.

- finalizacja projektów finansowanych z grantów,

Respondent 4: Najwięcej pracy miałem w instytucji, w której były dotacje i pomimo tego, że były nieopłacalne, musiały się odbyć, np. były streamowane na Facebooku i YouTubie.

\section{Przyszlość}

Przyszłość, jaka rysuje się przed respondentami, ma charakter krótkoterminowy, choć rozpiętość czasowa jest tu znacząca - od 3 do 6 miesięcy. Duża niepewność przyszłości wymusza na tych podmiotach postawę przedsiębiorczą. Respondenci w bardzo różny sposób podchodzą do kwestii podtrzymania działalności gospodarczej, akcentując znaczenie kreatywnego myślenia o strategii przetrwania. Dla podmiotów gospodarczych działających w obszarze kultury, gdzie dominują MŚP i umowy cywilnoprawne, niezwykle istotne jest myślenie o przyszłości osadzone w teraźniejszości, w bieżących dochodach, na przykład w czasach prosperity.

Respondent 2: W naszej branży każdy na skalę swoich możliwości powinien się zabezpieczać finansowo na bieżąco. Odkładać jakąś część swoich zarobków na czarną godzinę. Jeżeli ktoś jest na granicy finansowej działalności artystycznej i nie jest w stanie nic odłożyć, to mruga żółte światełko. Bo albo trzeba się przebranżowić, albo coś nie funkcjonuje. 
Respondent 1: Byliśmy zabezpieczeni, mieliśmy pieniądze na inwestycje, ale je wydaliśmy. Przygotowaliśmy się na rok bez pracy, ale ten rok minie w lutym.

Respondent 2: Myślę, że nie ma szans na drugi taki zastrzyk wsparcia.

Respondent 1: Zmienił się rynek pracy. Było trudno o pracownika, teraz otrzymujemy stos CV. Rynek pracownika zmienił się na rynek pracodawcy".

Respondent 4: Co z tego, że ja mam ten stół, jak ja nie mam co na nim robić teraz. Rząd z jednej strony robi dotacje, to jest generalnie w błoto na ten moment. Bo jeśli chodzi o refundowanie i odliczanie strat, które się poniosło, to spoko. Ale jeśli chodzi o to, co będzie do przodu, to trochę bez sensu. Bo jeśli będzie rozliczenie za kilka miesięcy, ile zrobiłem imprez np. w marcu, to pewnie wpiszę „O” i okaże się, że projekt działa wstecz, ale nie działa „do przodu”.

\section{Podsumowanie}

Polska jest jednym z niewielu krajów, gdzie środki na wsparcie usług scenotechnicznych znalazły się w dedykowanym branży programie. W wielu krajach zdecydowano się na rozdzielenie konkursów na reaktywne i proaktywne, a wsparcie kultury realizowane jest $\mathrm{w}$ ramach ogólnych programów rekompensujących straty dla przedsiębiorców lub rzadziej jako pomoc w transformacji umożliwiającej dostosowanie do nowych warunków działania.

Połączenie wielu funkcji w jednym funduszu okazało się zadaniem karkołomnym. Reaktywna funkcja była niezrozumiała dla osób, które - przyzwyczajone do proaktywnego finansowania kultury - miały trudności ze wskazaniem kosztów przedsięwzięcia do sfinansowania $\mathrm{z}$ funduszu. Skupienie natomiast na rekompensatach nie dawałoby nadziei i możliwości przyszłościowego spojrzenia na branżę. Tym bardziej, że uzasadnienie dla proaktywnych działań w projekcie znajduje wyjaśnienie w największych bolączkach sektora, dotyczących ponownego uruchomienia działalności oraz odbudowania widowni. Pozostaje jednak pytanie, czy koniec roku 2020 stanowił odpowiedni czas do pierwszych działań proaktywnych ze względu na nieprzewidywalny rozwój epidemii. Wielu respondentów nie podjęło się próby przewidywania tak odległej sytuacji.

Fundusz Wsparcia Kultury, pomimo że posiadał imponującą alokację środków, nie był w stanie odpowiedzieć na bardzo liczne wyzwania, z którymi organizatorom wydarzeń scenicznych przyjdzie się mierzyć niebawem, niemniej jednak tchnął nadzieję i zapewnił utrzymanie działalności jego beneficjentów przynajmniej do czerwca 2021 roku, kiedy to liczymy na możliwość organizacji wydarzeń plenerowych i przynajmniej częściowe podniesienie się branży. 


\section{Biblioggrafia}

Aagaard K. (2019), Quality Criteria and Concentration of Research Funding, https://www.r-quest. no/wp-content/uploads/2019/12/R-Quest_Policy_brief_4_2019.pdf [odczyt: 12.01.2021].

Abdoul H. (2012), Peer Review of Grant Applications: Criteria Used and Qualitative Study of Reviewer Practices, „PLoS ONE”, Vol. 7, No. 9.

Arensbergen P. van, Besselaar P. van den (2012), The Selection of Scientific Talent in the Allocation of Research Grants, „High Education Policy”, Vol. 25, Iss. 3, s. 381-405.

Banks M., O’Connor J. (2020), "A Plague upon Your Howling”: Art and Culture in the Viral Emergency, „Cultural Trends”, Vol. 30, No. 1.

Baumol W.J., Bowen W.G. (1966), Performing Arts, The Economic Dilemma: A Study of Problems Common to Theater, Opera, Music, and Dance, Cambridge, Mass.: MIT Press.

Betzler D., Loots E., Prokůpek M., Marques L., Grafenauer P. (2020), COVID-19 and the Arts and Cultural Sectors: Investigating Countries' Contextual Factors and Early Policy Measures, „International Journal of Cultural Policy”, s. 1-19.

Czyżewski K. (2020), Raport kultura. Pierwsza do zamknięcia, ostatnia do otwarcia. Kultura w czasie pandemii COVID-19, Kraków: Fundacja GAP.

DCMS \& Creative Industries Task Force (1998), Creative Industries 1998: Mapping Documents, London: Arts Council England.

Drobniak A. (2005), Ocena projektów publicznych, Katowice: Wydawnictwo Akademii Ekonomicznej w Katowicach.

Działalność przedsiębiorstw o liczbie pracujących do 9 osób w 2019 r. (2020), Warszawa: GUS.

Flew T. (2013), Global Creative Industries, Cambridge: Polity Press.

Fundusz Wsparcia Kultury, Instytut Teatralny, https://www.instytut-teatralny.pl/fundusz-wsparcia-kultury/ [odczyt: 12.01.2021].

Fundusz Wsparcia Kultury, MKiDN, https://www.gov.pl/web/kultura/fundusz-wsparcia-kultury/ [odczyt: 12.01.2021].

Harney S. (2010), Creative Industries Debate, „Cultural Studies”, Vol. 24, No. 3, s. 431-444.

Jasudowicz T. (2019), Wybrane problemy administracji w świetle standardów europejskich, Toruń: Monografie Kolegium Jagiellońskiego.

Kopeć K. (2014), Finansowanie kultury w ramach społecznej odpowiedzialności przedsiębiorstw, Kraków: Libron.

Leksykon budżetowy, http://sejm.gov.pl/Sejm7.nsf/BASLeksykon.xsp?t=s\&id=63AE1CB1AFC 5C5F1C1257A5600465DA7\&q=dotacje [odczyt: 12.01.2021].

Lewandowska K., Smolarska Z. (2019), Striving for Consensus: How Panels Evaluate Artistic Productions, „Qualitative Sociology”, Vol. 43, s. 21-42.

Pasikowska-Schnass M. (2020), EU Support for Artists and the Cultural and Creative Sector during the Coronavirus Crisis, https://www.europarl.europa.eu/RegData/etudes/BRIE/2020/649414/ EPRS_BRI(2020)649414_EN.pdf [odczyt: 12.01.2021]. 
Pawlak B. (2020), Kontrowersje wokót Funduszu Wsparcia Kultury. Jak wyliczono pomoc?, https://next.gazeta.pl/next/7,151003,26512303,kontrowersje-wokol-funduszu-wsparcia-kultury-jak-wyliczono.html [odczyt: 12.01.2021].

Ustawa z dnia 2 marca 2020 r. o szczególnych rozwiązaniach związanych z zapobieganiem, przeciwdziałaniem i zwalczaniem COVID-19, innych chorób zakaźnych oraz wywołanych nimi sytuacji kryzysowych (Dz.U. 2020, poz. 374), https://isap.sejm.gov.pl/isap.nsf/ DocDetails.xsp?id=WDU20200000374 [odczyt: 12.01.2021].

Zybała A. (2017), Pojęcie zasobów w polityce publicznej - rola i znaczenie dla budowania potencjału do efektywnego działania, [w:] J. Gardawski, R. Towalski (red.), Świat pracy: instytucje i wartości, Warszawa: Oficyna Wydawnicza SGH, s. 73-93. 